Hipotenusa : Journal of Mathematical Society

Volume 3 Issue 1 Year 2021

ISSN: $2716-3156$

Website: https://hipotenusa.iainsalatiga.ac.id/index.php/hipotenusa/index

\title{
An Analysis of Proportional Reasoning Ability of Secondary School Students on Opportunity Material Viewed from Gender Perspective
}

\author{
Kusnul Khotimah $^{1 *}$, Ali Shodikin ${ }^{1}$ \\ ${ }^{1}$ Universitas Islam Darul Ulum Lamongan \\ *Corresponding Author, email: khotimahbadallamut@gmail.com \\ DOI: 10.18326/hipotenusa.v3i1.111-128
}

Article submitted : February 4, 2021

Article reviewed : April 23, 2021

Article published : June 1, 2021

\begin{abstract}
This study aims to analyze the proportional reasoning ability of junior high school level students in solving math problems between male and female students on the opportunity material. This type of research is qualitative research. The subjects in this study were students of class VIII who were selected through the purposive sampling technique. Data collection methods are tests and interviews. The instruments used were the math ability test (TKM), proportional reasoning test (TPP) and interviews. Data were analyzed using the interactive model of Miles and Huberman. The validity of the data was tested by means of triangulation. The results showed that in the opportunity material, the male student subject was able to reach the entire level stage and fulfil the characteristics of proportional reasoning, while the female student subject was only able to reach level 1, while at level 2, the subject was unable to recognize the problem situation given was a proportional situation, at levels 3, 4 and 5 are unable to use multiplicative strategies so that they do not fulfil the characteristics of proportional reasoning. The research results are expected to be considered in determining learning strategies so that students master mathematical competencies optimally.
\end{abstract}

Keywords: Proportional Reasoning, Probability, Gender.

\section{INTRODUCTION}

Mathematics is one of the fundamental sciences. It exists in another branch of science. With its existence, mathematics is also known as the mother of knowledge. As a subject, mathematics is currently taught from primary education to higher education.

Mathematics which is taught at schools has an important role in developing students' competence. In the Regulation of the Minister of Education and Culture (Permendikbud) Number 22 of 2016 concerning the objectives of learning mathematics, it is stated that mathematics learning aims to 1) understand mathematical concepts, describe how the interrelationship between mathematical concepts or logarithms and 


\section{Hipotenusa Journal, 3 (1), June 2021 \\ Kusnul Khotimah, Ali Shodikin}

their implementation in an efficient, flexible, accurate, and precise manner in solving the problem; 2) reason the nature of mathematics, developing or manipulating mathematics in preparing arguments, formulating evidence, or describing mathematical argument and statement; 3) solve mathematical problems which include the ability to understand problems, formulate mathematical solving models, solve mathematical models, and provide appropriate solutions; and 4) communicate argument or idea with diagram, table, symbol, or other media in order to clarify the problem or situation. Based on this description, it can be understood that the purpose of learning mathematics is related to understanding and the ability to apply mathematical concepts to solve problems, make reasoning on trait pattern, compile argument and evidence, solve mathematical problem, and communicate argument or idea.

The objectives of learning mathematics are in line with the principles of mathematics learning as stated by the National Council of Teachers of Mathematics (NCTM), namely mathematics for problem-solving, (b) mathematics for reasoning, (c) mathematics for communication, and (d) mathematics for connection. These learning principles provide a reference for mathematics educators regarding the direction to go in learning mathematics, namely, to solve problems, reason, communicate, and connect (NCTM, 2000).

Mathematics has an important role in developing students' thinking skills. Mathematics is also a prime vehicle for developing children's logical thinking and higher-order cognitive skills (Muijs \& Reynolds, 2011). Based on this statement, the ability to think logically and high-level cognitive skills can be learned through mathematics. It is also one of the elements needed in the process of developing human resources. The important role of mathematics is asserted by (Cockcroft, 1982) "It would be very difficult-perhaps impossible-to live a normal life in very many parts of the world in the twentieth century without making use of the mathematics of some kind." It means that it is difficult or impossible for someone to live in this part of the earth in 20th century without the slightest use of mathematics. Often in mathematics learning, students tend to dislike it because it is considered very complicated and makes students complain when given math problems.

There are many concepts in mathematics that require students to use reasoning. In learning mathematics, reasoning skills are needed. The reasoning is a thought process in 


\section{Hipotenusa Journal, 3 (1), June 2021}

Kusnul Khotimah, Ali Shodikin

drawing a conclusion in the form of knowledge (S. Suriasumantri, 2013). Vince (Permatasari et al., 2017) state that the "cognitive process of looking for reasons, beliefs, conclusions, and actions". Through this statement, we know that reasoning is a cognitive process in finding reasons, beliefs, conclusions, and actions. When students carry out the thought process in determining these reasons, beliefs, conclusions, and actions, students are using their reasoning.

Fatmaningrum states that students'reasoning abilities are different from one another, but their abilities to solve math problems are very important and can be done through various ways of solving (Yuwono \& Putri, 2020). Reasoning is a basic skill in mathematics and is needed to achieve several objectives, for example, to understand mathematical concepts, to use more flexible mathematical ideas and procedures and to reconstruct previously understood knowledge but it is forgotten (Ball \& Bass, 2003). This statement shows that in the learning process, reasoning has a very important role in understanding concepts, using ideas and procedures, and reconstructing knowledge.

Reasoning also has an important role for students' achievement. The research findings by Setiana et al. (Setiana et al., 2020) states that there is a positive correlation between reasoning and mathematics achievement, between emotional intelligence in social interactions and mathematics achievement, and there is a positive correlation between reasoning and emotional intelligence in social interactions and mathematics achievement. Through this study, it is expected that it can be used as a basis for developing mathematics achievement through student reasoning, developing mathematics achievement through emotional intelligence in social interaction, and developing mathematics achievement through reasoning and emotional intelligence in social interactions (Setiana et al., 2020). Therefore, the reasoning is one of the skills that need to be developed in learning mathematics.

There are various kinds of mathematical reasoning, one of which is proportional reasoning. Lamon as stated by Walle (Permatasari et al., 2017) reveals that when doing proportional reasoning, a person has characteristics that include 1) Understanding covariation, 2) Recognizing proportional and non-proportional situations, 3) Applying multiplicative strategies, and 4) Understanding the use of ratio. Dolle, et al as quoted by Irpan state that fraction, percentage, ratio, decimal, scale, and algebra, require proportional reasoning (Eka \& Susanah, 2013). Proportional reasoning involves the 


\section{Hipotenusa Journal, 3 (1), June 2021 \\ Kusnul Khotimah, Ali Shodikin}

understanding of multiplication relationship between two or more quantities (Boyer et al., 2008). Post, Behr, \& Lesh and van de Walle state that the reason used to show that two numbers are similar in a proportional relationship is known as proportional reasoning (Johar et al., 2018).

Hino and Kato as quoted by $\mathrm{Im} \&$ Jitendra state that proportional reasoning is a complex way of thinking about interconnected ideas such as multiplication and division in integer, fraction, ratio, power, measurement, and percentage (Yuwono \& Putri, 2020). According to Irpan proportional reasoning is a mental activity in coordinating two quantities related to the change in relation (same value or reversal of value) of a quantity to another quantity (Arianti et al., 2017). Kilpatrick (in Nugraha et al., 2016) states that proportional reasoning is the understanding of fundamental relationship in a proportional situation and at the same time it uses these so-called relationships.

The thing especially those related to proportional term, Walle states that it is a statement of the equality of two ratios, while the ratio is a number that connects two quantities or sizes in certain situations to a multiplication relationship (Nugraha et al., 2016). Lamon (Permatasari et al., 2017) states "proportional reasoning involves the deliberate use of multiplicative relationships to compare quantities and to predict the value of one quantity based on the values of another". This statement implies that proportional reasoning involves deliberate multiplication relationships to compare quantities and to predict the value of one quantity based on the value of another quantity.

Proportional reasoning has several levels. Langrall \& Swafford (Sari \& Mampouw, 2019) state that 1) level 0 which is non-proportional reasoning includes guessing using visual cues, being unable to recognize multiplicative relationships, using random numbers, operations or strategies, not being able to connect two measures; 2) level 1, namely informal reasoning regarding proportional situations consisting of using images, models, or manipulatives to understand the situation and make qualitative comparisons; 3) level 2, quantitative reasoning, it unitizes or uses composite units, finds and uses unit rates, identifies or uses scalar factors or tables, uses equivalent fractions, and constructs both measures; 4) level 3, formal proportional reasoning which includes determining proportions using variables and solving problems using the cross-product 


\section{Hipotenusa Journal, 3 (1), June 2021 \\ Kusnul Khotimah, Ali Shodikin}

rule or equivalent fractions and fully understanding the invariance and covariance relationships.

Dole states that topics in the school mathematics and science curriculum require knowledge and understanding of proportions, and being able to reason proportionally (Sari \& Mampouw, 2019). This statement shows that knowledge of proportion is needed in both the mathematics curriculum and the science curriculum. Through proportional reasoning, students strengthen their knowledge of elementary school mathematics and build a foundation for middle school mathematics (Langrall \& Swafford, 2000).

Proportional reasoning is very useful in everyday life. Walle as quoted by Nugraha, et.al (Yuwono \& Putri, 2020) state that in everyday life, there are many problems regarding proportional situations, including comparisons in pricing, use of scales in maps, solving problems about percentages, use of scale in designing a building, and many more. This statement shows that proportional reasoning is useful in the fields of social, spatial, arithmetic, engineering, and so on.

According to Piaget, as stated by Irawati (Yuwono \& Putri, 2020), proportional reasoning is defined as a qualitative structure of reasoning, in which understanding may be complex and contain many factors, such as the understanding which is related to proposition or ratio. For example, note that the ratio between a and $\mathrm{b}$ is 3 , a and $\mathrm{c}$ are 2 ; then what is the ratio of a and $\mathrm{c}$ ? To answer this question, the child's thinking process is in proportional reasoning (Yuwono \& Putri, 2020).

If this proportional reasoning is not well developed, the result will not be optimal for student learning development. Due to the large number of mathematical materials that involve proportional reasoning, and if the students' proportional reasoning does not develop properly, students will get difficulties in learning mathematics (Eka \& Susanah, 2013).

Viewed from their cognitive development, junior high school students are at the formal operational stage. This refers to Piaget's theory of cognitive development that children at the age of 12 years and over are in the development of formal operational thinking (Ibda, 2015; Juwantara, 2019). This stage of formal operational thinking is also stated to take place at the age of eleven to fifteen (Mu'min, 2013). 


\section{Hipotenusa Journal, 3 (1), June 2021 \\ Kusnul Khotimah, Ali Shodikin}

Santrock (Prastowo, 2014) states that at the formal operational stage, students are able to think more abstractly, idealistically, and logically. Students at the formal operational stage can solve problems even though these problems are only presented verbally. They are able to idealize, imagine a number of possibilities, develop deductive hypotheses about how to solve problems and reach conclusions systematically (Mu'min, 2013).

In relation with this cognitive development, Piaget provides suggestions on how to facilitate students' learning, namely: (1) realizing that there are many students who are not perfect formal operational thinkers; (2) posing a problem, inviting students to formulate hypotheses about how to solve it; (3) giving a problem and suggestion on several ways to solve the problem, then ask questions that encourage students to evaluate this method; (4) selecting a well known particular problem to students in the class and ask questions related to the problem; (5) asking students to discuss their conclusions in advance; (6) getting students involved in a project and an investigation; (7) encouraging students to arrange hierarchical explanations for writing; and (8) admitting that students are more likely to use formal operational thinking in areas where students have a lot of expertise and experience in the area (Mu'min, 2013). These suggestions show that junior high school students are very appropriate to join the activities that involve the scientific method and reasoning skills.

Basically, every student has a different level of proportional reasoning ability. The reasoning ability of male students is better than that of female students (Benbow et al., 2000). Thus, the differences in abilities owned by male and female students affect different proportional reasoning in solving math problems. There are many kinds of strategies for solving problems, namely the unit rate strategy, the change factor strategy, the build-up method, the cross-fold strategy, and unitizing strategy (Avcu \& Avcu, 2010). The use of these strategies involves proportional situations between different male and female students. The strategies of female students are different from male students in solving problems that involve proportional situations (Steinthorsdottir \& Sriraman, 2007). Other research findings were shown by Benbow and the team which stated that male students' reasoning abilities were better than that of female students (Benbow et al., 2000). Thus, proportional reasoning differences in solving math problems are influenced by differences in abilities owned by male and female students. 


\section{Hipotenusa Journal, 3 (1), June 2021}

Kusnul Khotimah, Ali Shodikin

Proportional research on the problem of opportunity is not found yet. Whereas solving the opportunity problem also requires proportional reasoning, such as determining the probability of a certain event in the sample class, comparing the opportunities for two or more events, and analyzing certain events that occur more frequently. Based on the description above, further analysis of proportional reasoning in solving math problems for junior high school students on the opportunity material in terms of gender needs to conduct.

\section{METHOD}

This is qualitative research. The subjects of this research are eighth grade students of SMP in Lamongan Regency. For deep analysis, the researcher analyzed two students consisting of one boy and one girl that have the same math ability. The data were collected directly by the researcher, so the main research instrument was the researcher himself as the interviewer who was assisted by instruments in the form of probability problem-solving test questions and proportional reasoning questions. The techniques of collecting data used in this research are written test and interview in the form of confirmation of the subject's answers to proportional reasoning questions.

The data obtained from test and interviews were analyzed using the interactive model of Miles and Huberman through the stages of collection, presentation, reduction, and conclusion/verification by referring to the proportional reasoning component of students. The data were collected through test and interview to obtain the data regarding proportional reasoning abilities. At the data presentation stage, the researcher presents the data on proportional reasoning abilities, data on problem-solving abilities on the opportunity material, and the methods used by students in working on questions. At the data reduction stage, the researcher selects relevant data and separates it from irrelevant data to the research objectives. The conclussion stage, the author compares between proportional reasoning abilities and problem-solving abilities on the material opportunities obtained from the test with data about the methods taken by students in working on the questions obtained through interviews. At this stage, the writer also analyzes the similarity of the three data. In the end, the author draws the conclusion which is relevant to the research objectives.

In particular, on the test results, the researcher analyzed the data using descriptive statistics to determine the math ability score and proportional reasoning score. In 


\section{Hipotenusa Journal, 3 (1), June 2021 \\ Kusnul Khotimah, Ali Shodikin}

analyzing the data from the problem-solving test results, the researcher referred to the answer keys and scoring guidelines for the math ability test. This data analysis is used to select research subjects with equivalent abilities.

\section{RESULTS AND DISCUSSION}

Based on the research findings, it can be described as follows.

\section{Male Student Proportional Reasoning}

In the first question, students are asked to name the possible value of an event. Students are also asked to provide an explanation of the meaning of the opportunity value.

At Level 1 of Qualitative Reasoning, from the results of the completion made by male students, they are able to argue that the value of an opportunity is between 0 and 1 , events that have a definite probability value of 1 and impossible events have a value of 0 . The answers of male students are presented in the following figure:

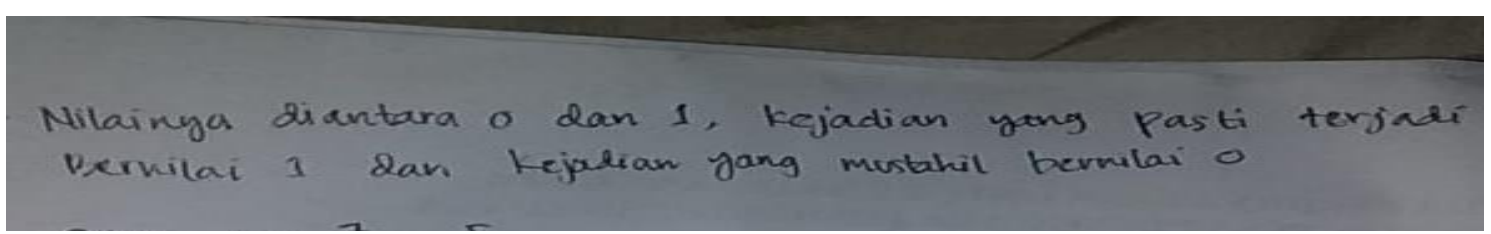

Figure 1. the answers of male students to the first question

This data is supported by interview data. The following is an quotation interview results with male students.

P: Have you ever studied this material?

S: I have

P: What do you understand from the problem?

S: The value of an event or chance, an event whose value is from $0-1.0$ for impossible thing and 1 for certain events.

Through the interview, it is known that the male students understand the fundamental concept of the opportunity value, which ranges from 0 to 1 . From the description, it is found that the proportional reasoning of male students is related to understanding covariation which includes the activity of explaining mutually variable quantities. This is in line with Lamon's (Park et al., 2010) statement that a person does proportional reasoning when he is faced with a situation that involves covariation relationships that occur among the quantities used.

At Level 2 of Additive Reasoning, the activity carried out by students is being able to compare quantities to find the one value being asked. The male students also argued that 


\section{Hipotenusa Journal, 3 (1), June 2021 \\ Kusnul Khotimah, Ali Shodikin}

for this type of problem it could be done with an additive relationship. The answers of male students are presented in the following figure:

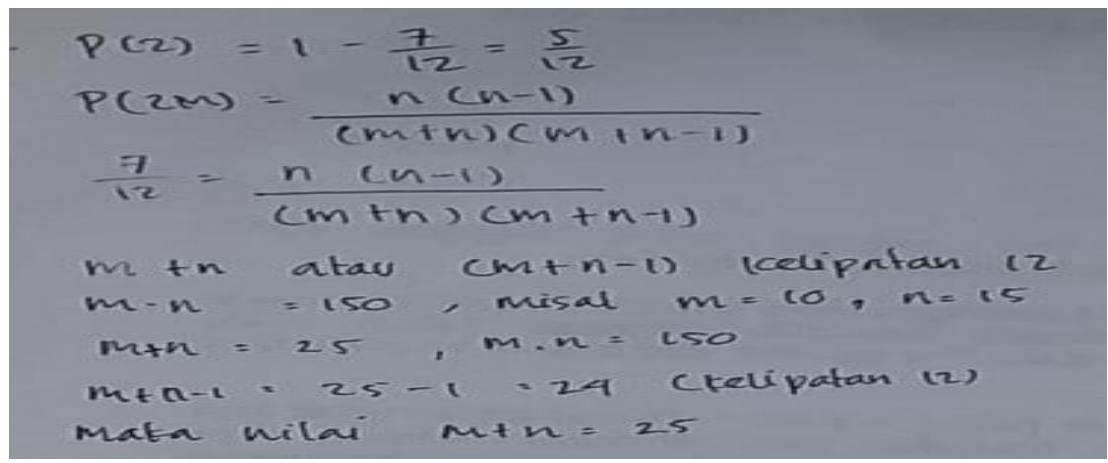

Figure 2. The answer of male students to the second questions

The data of test result is supported by interview data. The following is a quotation from interviews with male students.

P: Are you sure the method you chose is the right one?

S: Yes, question number 2 is a proportional question, it can be used additives.

Based on the description above, it was found that the activity performed by male students in solving the proble of "missing value" showed that he recognized the problem situation given as a proportional situation. When solving the the problem "missing value", male students represent quantities into ratios that form proportions, then use multiplication and division to get the value asked, in this case, the male students argued that they did not know a strategy other than a cross-river strategy to solve this problem (Permatasari et al., 2017).

Langrall \& Swafford (2000) state that one of the components in doing proportional reasoning is to recognize differences in changes in quantities caused by additive or multiplicative relationships from a given problem situation (Permatasari et al., 2017). The male students in this question understand that the problem at hand is proportional reasoning using additive methods. An understanding of this additive method is an important thing for students to have in learning mathematics. An understanding of additive methods will determine students' ability to develop mathematical abilities regarding mathematical objects. According to Walle, proportional reasoning represents the ability to begin to understand multiplication relationships where most arithmetic concepts are usually based on addition (Nugraha et al., 2016). 


\section{Hipotenusa Journal, 3 (1), June 2021}

Kusnul Khotimah, Ali Shodikin

Level 3 of Pre-Multiplicative Reasoning and Level 4 of Implicit Multiplicative Reasoning

At this level, the students' activities carried out by male students are as follows: (A) when solving the type of numerical comparison problem, male students represent quantities into a ratio then simplifies the ratio to a form, where the two quantities being compared are quantities in the same size and space. In applying the multiplicative strategy component, male students solve the problem of "numerical comparison" using the unit rate strategy (B). When solving the proble of "missing value" problem, male students represent quantities into ratios that form proportions, then students use the multiplication, division and addition to get the value asked. Furthermore, the male student stated that he did not know any strategy other than the cross-river strategy to solve the problem. The following is the work of male students:
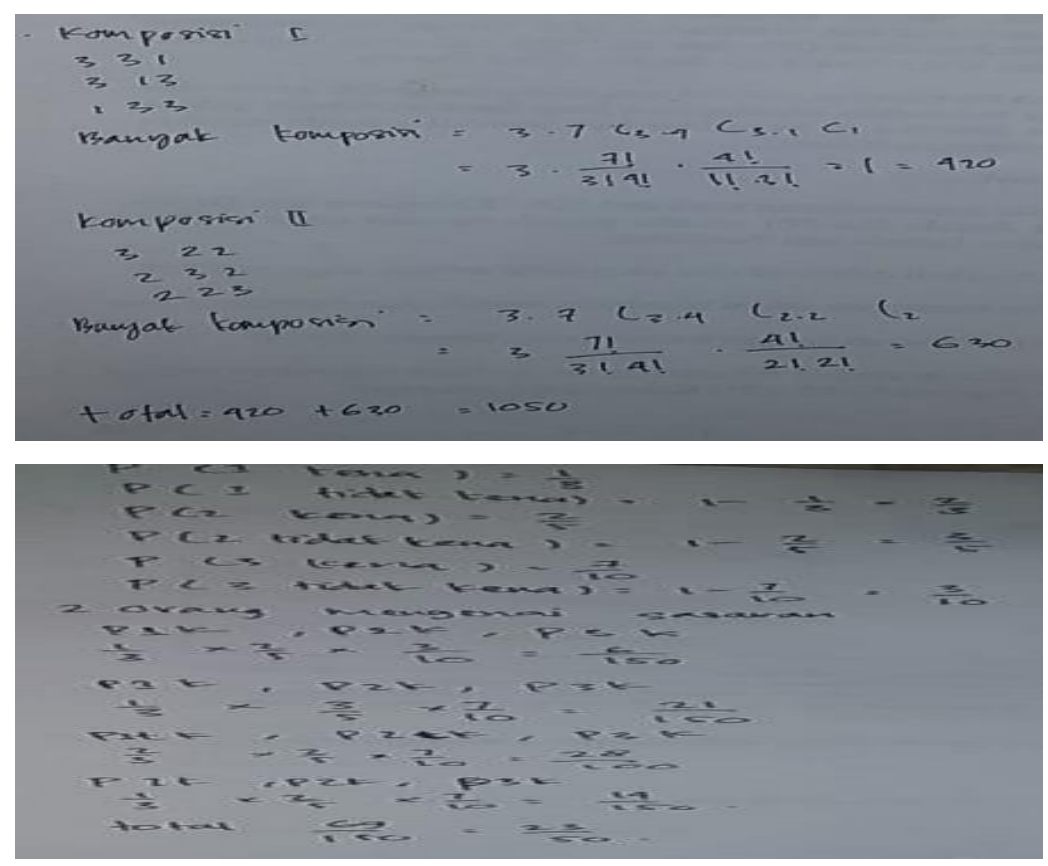

Figure 3 The answers of male students to the third questions

The data of test result is supported by interview results. The following is quotation of interviews with male students.

P: Why did you choose that method?

$\mathrm{S}$ : Because to solve this problem, it is necessary to use a multiplicative strategy to find unknown values.

$\mathrm{P}:$ Are you sure your answer is correct? 


\section{Hipotenusa Journal, 3 (1), June 2021 \\ Kusnul Khotimah, Ali Shodikin}

S: Yes, because I don't know any other strategies.

The students used a multiplicative strategy to find unknown values. They stated that they believed in the way they took. They also stated that they did not know other strategies. The activities shown by these students were in line with the results of research conducted by (Park et al., 2010) which asserted that the strategies students used depend on the context of the problem given.

\section{Level 5 Multiplicative Reasoning}

When solving problems at this level, male students are able to work on problems by calculating what is known with variables and linking it into other forms.

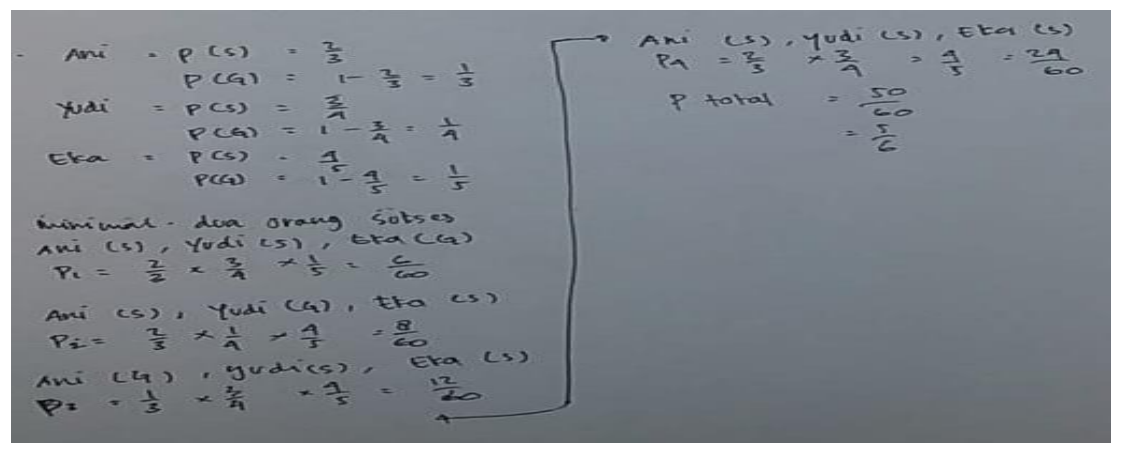

Figure 4. The answer of male students to the fourth question

The data of test result is also supported by results of interview. The following is quotation interview interviews with male students.

P: How did you get that answer?

$\mathrm{S}$ : By using variable examples to make it easier to work on and associated with a multiplicative strategy. In this condition, students use an example strategy. Students also use a multiplicative strategy.

\section{Proportional Reasoning of Female Student}

At Level 1 of Qualitative Reasoning, female students are able to argue that the value of an opportunity is between 0 and 1 , an event that has a probability value of 1 is a certain event, and while a probability value of 0 is an uncertain event to occur. The answers of the female students are described below:

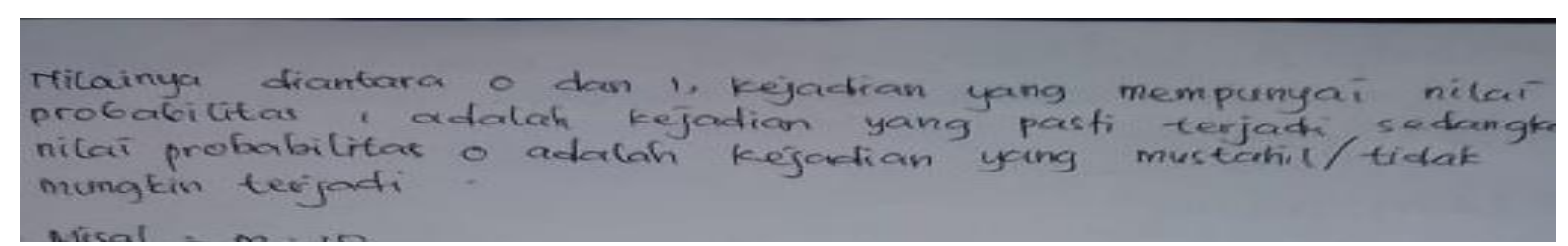

Figure 5. The answers of female studenst to the fisrt question 


\section{Hipotenusa Journal, 3 (1), June 2021}

Kusnul Khotimah, Ali Shodikin

The results of the female students' test were supported by the results of the interviews. The following is quotation of interview with female students.

P: Have you ever studied this material?

S: Yes, I have

P: What do you understand from this problem?

S: Value between 0 and 1 . An event that has a probability value of 1 is a certain event, while a value of 0 is an impossible event.

Through these interviews, students understood that the opportunity value is ranging between 0 and 1 . Students were also able to provide an explanation of the meaning of 0 and 1 . The opportunity value of 0 is impossible, while the opportunity value of 1 is certainty. Proportional reasoning of female students is related to understanding of covariation which includes the activity of explaining quantities that vary one another. This is in line with Lamon's statement (Park et al., 2010) that a person does proportional reasoning when he faces a situation involving the covariation relationship that occurs and between quantities used.

\section{Level 2 of Additive Reasoning}

The activity carried out by students is not able to compare quantities to find one value which is asked. The female students also argued that this type of problem could not be solved with additive relationships or using a multiplicative strategy. The following is the work of female students related to additive reasoning.

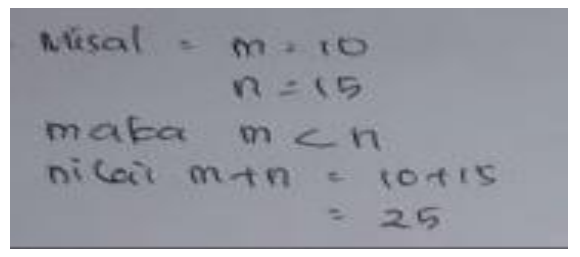

Figure 6. The answer of female students to the second question

The test results on these female students were supported by interviews. The following is quotation of the interview with femal students.

P: Are you sure the method you chose is the right one?

S: Yes, by looking for the numbers that match the conditions, and then entering them one by one to get the result.

Based on the description above, it was found that the activities performed by female students in solving the proble of "missing value" indicated that they were not 


\section{Hipotenusa Journal, 3 (1), June 2021}

Kusnul Khotimah, Ali Shodikin

able to recognize the problem given as a proportional situation. This is different from a study that states that female students recognize the problem given is a proportional situation (Permatasari et al., 2017). In that study, when solving the "missing value" problem, female students compared three known quantities to find a value that was asked. Female students also stated that this type of problem could not be solved with an additive relationship. When solving the "numerical comparison" problem, female students stated that the relationship between the two quantities, namely the number of animals/number of uniforms that are proper for sale against the number of animals sold as a result of the relationship is greater, smaller, or even equal (Permatasari et al., 2017)

Langrall \& Swafford (2000) state that one of the components in doing proportional reasoning is to recognize differences in changes in quantities caused by additive or multiplicative relationships from a given problem situation (Permatasari et al., 2017). If students are not able to recognize the problem situation, this has an impact on how students solve the problem.

\section{Level 3 of Pre-Multiplicative Reasoning and Level 4 of Implicit Multiplicative} Reasoning

At this level, female students solve the "missing value" problem by using the cross-fold strategy, while in solving the "numerical comparison" problem, they do not use a multiplicative strategy because they recognize that the situation of this type of problem is a non-proportional situation. The following is the result of the work of female students in relation to the third question.
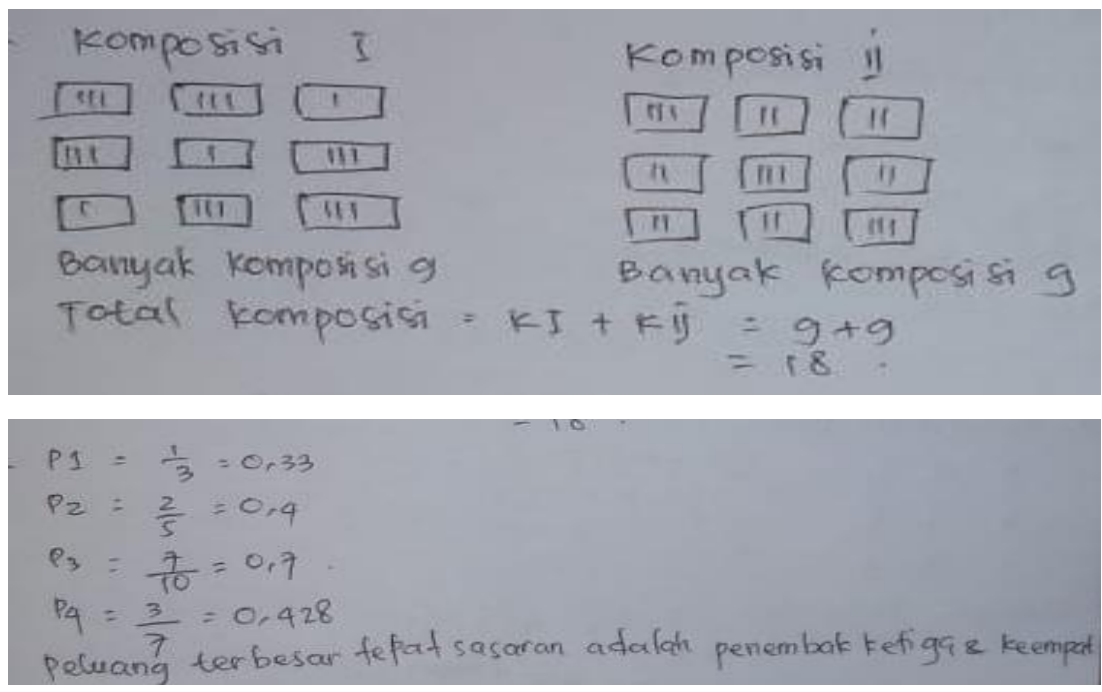

Figure 7. The answer of female students to the third question 


\section{Hipotenusa Journal, 3 (1), June 2021}

Kusnul Khotimah, Ali Shodikin

The results of the student's work were clarified with data from interviews. The following is quotation of interviews with female students.

P: Why did you choose that method?

S: Because to find the composition, we must draw the patterns one by one and find the biggest possibility. We can determine the quantity of opportunity by converting it into decimal fractions, and then you can see which one is the biggest.

$\mathrm{P}:$ Are you sure your answer is correct?

S: Yes

The activities performed by female students are in line with Norton's (2005) statement that using multiplication and division operations to solve problems involving proportional situations does not necessarily develop a deeper understanding of proportional reasoning (Yuwono \& Putri, 2020). This is reinforced by the statement (Park et al., 2010) which states that "an area identified as a problem type for which students not having learned a formal proportional expression cannot understand the multiplicative relationship very well". Through these statements, we understand that an area identified as a type of problem in which students who do not learn formal proportional expressions cannot properly understand the multiplication relationship.

\section{Level 5 of Multiplicative Reasoning}

When solving problems at this level, female students work on problems by not considering what is known with the variables and not representing the existing quantities in the form of ratios. The following are the results of the work of female students related to multiplicative reasoning.

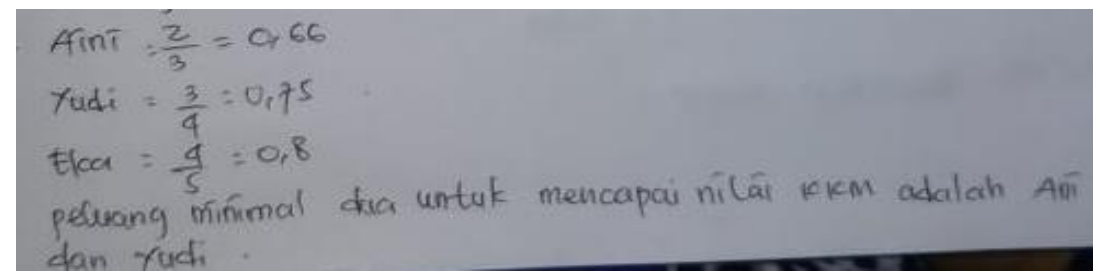

Figure 8 . The answers of female students to questions related to multiplicative reasoning

The answers of female students to questions related to multiplicative reasoning were supported by interview data. The following is quotation of interviews with female students. 


\section{Hipotenusa Journal, 3 (1), June 2021 \\ Kusnul Khotimah, Ali Shodikin}

P: How did you get that answer?

S: it's the same as the previous problem, I changed it to decimal form to find the smallest opportunity.

Based on the results of interview, it was found that students used a strategy of changing the form of numbers into decimal form. With this decimal form, it made it easier for students to find out the value of the smallest opportunity.

\section{CONCLUSION}

Based on the analysis and discussion of the data, it can be drawn a conclusion. In the component of understanding the covariation, male students are able to argue that the value of an opportunity is between 0 and 1 . The event that has a definite probability is 1 , and the event that is impossible to occur is 0 . In addition, male students are able to compare quantities to find one value which is asked. The male students also argued that this type of problem could be done with an additive relationship. Then in the component of understanding the terms of using ration, male students in this component understand the terms of usisng it, both in solving the problem of "missing value" and "numerical comparison". Male students present the compared quantities in the form of a ratio. In addition, it is known that male students have understood the form of the within ratio and the between ratio. Meanwhile, female students are able to express that the value of an opportunity is between 0 and 1 . An event that has a probability to occur is 1 , and an event that is impossible to occur is 0 . In addition, female students were unable to compare quantities to find the one value that was asked. They also argued that this type of problem could not be solved using an additive relationship or a multiplicative strategy. Then in the component of understanding, female students solved the problem of the "missing value" using the cross-fold strategy, while when solving the "numerical comparison" problem, the female students do not use a multiplicative strategy because they recognize that this type of problem is a non-proportional situation. In addition, it is known that female students worked on problems by not considering what is known with the variables and not representing the existing quantities in the form of ratio. 


\section{Hipotenusa Journal, 3 (1), June 2021 \\ Kusnul Khotimah, Ali Shodikin}

\section{REFERENCES}

Arianti, Fahinu, \& Ndia, L. (2017). Pengaruh Model Pembelajaran Berbasis Masalah terhadap Kemampuan Penalaran Proporsional Siswa Kelas VII 5 SMP Negeri 1 Lasalepa. Jurnal Penelitian Pendidikan Matematika, 5(1), 1-14.

Avcu, R., \& Avcu, S. (2010). 6th grade students' use of different strategies in solving ratio and proportion problems. Procedia - Social and Behavioral Sciences. https://doi.org/10.1016/j.sbspro.2010.12.320

Ball, D. L., \& Bass, H. (2003). Making Mathematics Reasonable in School. A Research Companion to Principles and Standards for School Mathematics.

Benbow, C. P., Lubinski, D., Shea, D. L., \& Eftekhari-Sanjani, H. (2000). Sex Differences in Mathematical Reasoning Ability at Age 13: Their Status 20 Years Later. Psychological Science. https://doi.org/10.1111/1467-9280.00291

Boyer, T. W., Levine, S. C., \& Huttenlocher, J. (2008). Development of Proportional Reasoning: Where Young Children Go Wrong. Developmental Psychology. https://doi.org/10.1037/a0013110

Cockcroft, W. . (1982). Mathematics Counts. In Report of the Committee of Inquiry into the Teaching of Mathematics in Schools in England and Wales.

Eka, R., \& Susanah. (2013). Penalaran Proporsional Siswa Kelas VII SMP Negeri II Beji Pasuruan Berdasarkan Tingkat Kemampuan Matematika. Jurnal Pendidikan Matematika, 2(1), 15-21.

Ibda, F. (2015). Perkembangan Kognitif: Teori Jean Piaget. Intelektualita, 3(1), 27-38.

Johar, R., Yusniarti, S., \& Saminan. (2018). The analysis of proportional reasoning problem in the Indonesian mathematics textbook for the junior high school. Journal Mathematics Education, 9(1), 55-68. https://doi.org/10.22342/jme.9.1.4145.55-68

Juwantara, R. A. (2019). Analisis Teori Perkembangan Kognitif Piaget pada Tahap Anak Usia Operasional Konkret 7-12 Tahun dalam Pembelajaran Matematika. AlAdzka: Jurnal Ilmiah Pendidikan Guru Madrasah Ibtidaiyah, 9(1), 27-34. https://doi.org/10.18592/aladzkapgmi.v9i1.3011 


\section{Hipotenusa Journal, 3 (1), June 2021 \\ Kusnul Khotimah, Ali Shodikin}

Mu'min, S. A. (2013). Teori Pengembangan Kognitif Jian Piaget. Jurnal AL-Ta'dib, 6(1), 89-99. https://doi.org/http://dx.doi.org/10.31332/atdb.v6i1.292

Muijs, D., \& Reynolds, D. (2011). Effective teaching: Evidence and practice. In Effective Teaching. Sage Publication, Inc.

NCTM, N. C. of T. of M. (2000). Executive Summary: Principles and Standards for School Mathematics Overview. In National Council of Teachers of Mathematics.

Nugraha, Y., Sujadi, I., \& Pangadi, P. (2016). Penalaran Proporsional Siswa Kelas VII. Beta Jurnal Tadris Matematika, 9(1), 34-47. https://doi.org/10.20414/betajtm.v9i1.2

Park, J. S., Jee, H. P., \& Oh, N. K. (2010). Characterizing the Proportional Reasoning of Middle School Students. The SNU Journal Of Education Research, 119-144.

Permatasari, D. I., Siti M, A., \& Wijayanti, P. (2017). Penalaran Proporsional Siswa SMP Kelas IX dalam Menyelesaikan Masalah Matematika ditinjau dari Gender. Kreano, Jurnal Matematika Kreatif-Inovatif, 8(2), 199-207. https://doi.org/10.15294/kreano.v8i2.9537

Prastowo, A. (2014). Pemenuhan Kebutuhan Psikologis Peserta Didik Sd/Mi Melalui Pembelajaran Tematik-Terpadu. JURNAL JPSD (Jurnal Pendidikan Sekolah Dasar). https://doi.org/10.26555/jpsd.v1i1.a538

S. Suriasumantri, J. (2013). Filsafat Ilmu sebuah Pengantar Populer. In Journal of Chemical Information and Modeling.

Sari, D. N., \& Mampouw, H. L. (2019). Analisis Kemampuan Penalaran Proporsional Siswa Sma Dalam Memecahkan Masalah Matematika. Math Didactic:Jurnal Pendidikan Matematika, 5(2), 110-122. https://doi.org/https://doi.org/10.33654/math.v5i1.569

Setiana, D. S., Nuryadi, \& Santoso, R. H. (2020). The Correlation between Reasoning and Emotional Intelligence in Social Interaction to Mathematics Achievement. Hipotenusa Journal of Mathematical Society, 2(1), 21-25. https://doi.org/https: //doi.org/10.18326/hipotenusa.v2i1.21 - 25

Steinthorsdottir, O. B., \& Sriraman, B. (2007). Gender and strategy use in proportional 


\section{Hipotenusa Journal, 3 (1), June 2021 \\ Kusnul Khotimah, Ali Shodikin}

situations: an Icelandic study. Nordic Studies in Mathematics Education, 12(3), xy.

https://www.academia.edu/4126902/Gender_and_strategy_use_in_proportional_sit uations_an_Icelandic_study

Yuwono, I., \& Putri, A. A. (2020). Analisis Penalaran Proporsional Pada Siswa Kesulitan Belajar Matematika Di Sekolah Inklusif. E-Jurnal Matematika, 9(4), 288. https://doi.org/10.24843/mtk.2020.v09.i04.p311 